\title{
pH Standards of High Acidity and High Alkalinity and the Practical Scale of $\mathrm{pH}$
}

\author{
By Roger G. Bates, Gladys D. Pinching, and Edgar R. Smith
} cell

The practical scale of $\mathrm{pH}$ is defined in terms of the electromotive force of the galvanic

$$
\mathrm{Pt} ; \mathrm{H}_{2}(g) \text {, solution | satd. } \mathrm{KCl} \mid \text { standard, } \mathrm{H}_{2}(g) ; \mathrm{Pt} \text {. }
$$

This potential is usually obtained as the difference of two electromotive force values for a cell with glass and calomel electrodes, one of which is a calibration with a standard of known $\mathrm{pH}$. Appropriate corrections must be applied if the glass electrode does not respond to changes in hydrogen-ion activity in exactly the same manner as the hydrogen electrode. However, there is no simple means of correcting $\mathrm{pH}$ measurements for the potential differences at the junctions of the solution and the standard with the solution of potassium chloride. These errors are sufficiently large in highly acid and highly alkaline solutions to render uncertain the interpretation of measured $\mathrm{pH}$ in these regions, in spite of the fact that reasonably accurate standards of hydrogen-ion activity are available at intermediate $\mathrm{pH}$ values.

The purpose of this study was twofold: (a) to determine the extent of aberration of the practical $\mathrm{pH}$ scale near its ends, and (b) to select new standards that might improve the accuracy of $\mathrm{pH}$ measurements and facilitate their interpretation over the entire practical scale, with particular attention to the regions of high acidity and high alkalinity. The results indicate that $\mathrm{pH}$ obtained by adjustment of the meter with the present standards (phthalate, $\mathrm{pH} 4.01$ at $25^{\circ} \mathrm{C}$; phosphate, $\mathrm{pH} 6.86$; borax, $\mathrm{pH} 9.18$ ) will usually be low by at least 0.02 to 0.05 unit above $\mathrm{pH} 11$, while errors as great as 0.03 unit, either positive or negative, are not uncommon below $\mathrm{pH}$ 2.5. The following additional standards were selected to supplement the three presently available: (1) $0.01-M$ potassium tetroxalate$\mathrm{pH} 2.15$ at $25^{\circ} \mathrm{C} ;(2)$ potassium hydrogen tartrate (saturated at room temperature) $-\mathrm{pH}$ 3.56 ; (3) $0.025-M$ sodium acid succinate, $0.025-M$ sodium succinate $-\mathrm{pH} 5.40$; (4) $0.025-M$ sodium bicarbonate, $0.025-M$ sodium carbonate $-\mathrm{pH} 10.02$; and (5) $0.01-M$ trisodium phosphate- $\mathrm{pH}$ 11.72. The choice was based on a comparison of $\mathrm{pH}$ derived from cells with and without liquid junction in a study of 41 promising standard solutions. The $\mathrm{pH}$ on the practical scale was determined at $25^{\circ} \mathrm{C}$, and electromotive force measurements of hydrogen-silver chloride cells without liquid junction were made at $0^{\circ}, 10^{\circ}, 25^{\circ}$, and $38^{\circ} \mathrm{C}$.

\section{Introduction}

Recent demands for methods and standards for the accurate measurement of acidity and alkalinity have stimulated interest in the meaning of the $\mathrm{pH}$ scale so widely used today. The $\mathrm{pH}$ may be regarded on the one hand as a measurable property of many diverse materials, a property capable of adequate measurement by one of the commercially available electrometric instruments. From the point of view of the physical chemist, however, the $\mathrm{pH}$ value is usually regarded as conveying some information concerning the effective concentration or activity of hydrogen ions, $a_{\mathrm{H}}$, in the solution in question. Carried to extremes, the first point of view reduces $\mathrm{pH}$ to an empirical number the quantitative interpretation of which is unimportant, if not impossible. The second approach creates a $\mathrm{pH}$ unit with meaning but offers no simple method of measuring acidity in terms of it. The conflict between $\mathrm{pH}$ as an empirical number in routine control and as a significant concept in research work has caused much confusion.

Fortunately, a compromise between the two extreme views is possible. Although the need for a practical scale demands that $\mathrm{pH}$ be defined from the operational point of view [1 to 4], ${ }^{1}$ it is certainly desirable that this scale be adjusted in any way

\footnotetext{
1 Figures in brackets indicate the literature references at the end of this paper.
}

necessary to endow the measured $\mathrm{pH}$ numbers with a certain amount of significance in terms of hydrogen ion. To see how this can be accomplished, let us consider the practical determination of $\mathrm{pH}$.

Commercial $\mathrm{pH}$ instruments almost universally employ a cell composed of a glass electrode (with inner reference) and a calomel electrode, together with a bridge solution saturated with potassium chloride:

(glass, inner ref.), solution | satd. $\mathrm{KCl}, \mathrm{Hg}_{2} \mathrm{Cl}_{2} ; \mathrm{Hg}$, (I)

where the vertical line indicates a boundary between two different solutions. The hydrogen, quinhydrone, or antimony electrode may replace the glass electrode. The calomel serves as a reference electrode for the measurement of the potential of the glass electrode, which is a function of the hydrogenion activity. Reference electrodes other than calomel are rarely used. Although the hydrogen gas electrode is the primary standard for hydrogen-ion measurements, the versatile glass electrode serves satisfactorily when the corrections necessary in alkaline solutions (and to a lesser degree in strongly acid solutions) are applied.

Unfortunately, no known cell can furnish an exact practical measurement of either the activity or the concentration of hydrogen ion. Furthermore, the usual forms of the convenient glass and calomel 
electrodes are not sufficiently reproducible and constant in potential to permit the same relationship between emf and $\mathrm{pH}$ to be used for long periods of time. This latter difficulty is readily circumvented by frequent calibration of the instrument with standards of known or assigned $\mathrm{pH}$. The actual potential of the glass-calomel cell is then unimportant. The difference of potential, $E-E_{s}$, resulting from replacement of the standard $\mathrm{S}$ (the $\mathrm{pH}$ of which is designated $\mathrm{pH}_{s}$ ) by the unknown solution is of sole concern. Hence, the practical definition of $\mathrm{pH}$ is formulated as follows,

$$
\mathrm{pH}=\mathrm{pH}_{s}+\frac{\left(E-E_{s}\right) \boldsymbol{F}}{2.3036 R T},
$$

where $\boldsymbol{F}$ is the faraday, 96,496 abs coulombs per equivalent [5]; $R$ is the gas constant, 8.3144 abs $\mathrm{j} \mathrm{deg}^{-1} \mathrm{~mole}^{-1}[5]$; and $T$ is the temperature on the absolute, or Kelvin, scale, $\left({ }^{\circ} \mathrm{C}+273.16\right)$. At $25^{\circ} \mathrm{C}$, $2.3026 R T / \boldsymbol{F}$ is 0.059154 .

The validity of eq 1 rests upon two assumptions. First, it is implied that replacement of the standard by the unknown causes no change in either the sign or magnitude of the potential difference across the boundary between the saturated solution of potassium chloride and the solution in contact with it. Second, eq 1 assumes that the potential of the electrode reversible to hydrogen ion (the glass electrode in cell I) changes by $2.3026 R T / \boldsymbol{F} \mathrm{v} / \mathrm{pH}$ unit, as does the standard hydrogen electrode. If this is not the case, corrections must be applied for the imperfect response of the electrode. The sodiumion error of the glass electrode in alkaline solutions provides a common example of departure from the theoretical response. The hydrogen electrode is usually chosen for standardization work in order to obviate the necessity of applying these empirical and often approximate corrections.

Evidently $E-E_{s}$ is independent of the reference electrode employed. Indeed, if the potential of the glass electrode changes by the same amount as does the hydrogen electrode for a given change of hydrogen-ion activity, $E-E_{s}$ represents the electromotive force of the cell

$$
\mathrm{Pt} ; \mathrm{H}_{2}(g) \text {, solution }\left|\begin{array}{c}
\text { satd. } \\
\mathrm{KCl}
\end{array}\right| \text { standard, } \mathrm{H}_{2}(g) ; \mathrm{Pt} \text {, }
$$

in which a saturated solution of potassium chloride is interposed directly between the solutions of known and unknown $\mathrm{pH}$.

As has already been indicated, the $\mathrm{pH}$ cannot be interpreted with exactness. The meaning of the values furnished by eq 1 rests upon the adequacy of the relationship between $\mathrm{pH}-\mathrm{pH}_{s}$ and $E-E_{s}$, and the meaning of the $\mathrm{pH}$ number, $\mathrm{pH}_{s}$, assigned to the standard. Corrections for liquid-junction potentials, which might effect some improvement of eq 1 , are inaccurate and laborious, and hence out of the question for practical measurements. However, the utility of this scale is not impaired by assignment of $\mathrm{pH}$ values that represent as closely as possible the presumed hydrogen-ion activity in the standard solution, and by this means the interpretation of the measured $\mathrm{pH}$ may be somewhat clarified.

In order to avoid some of the troublesome features of the hydrogen-calomel cell, it is logical to turn to a cell without liquid junction for the important task of establishing standards. That composed of hydrogen and silver-silver-chloride electrodes is probably the most suitable. For the purpose at hand, this cell can be represented

$$
\left.\mathrm{Pt} ; \mathrm{H}_{2} \text { ( } g, 1 \mathrm{~atm}\right) \text {, solution, } \mathrm{KCl}(m), \mathrm{AgCl} ; \mathrm{Ag} .
$$

The emf, $E$, is a function of the temperature and of the activities of hydrogen and chloride ions in the solution surrounding the two electrodes. It is convenient to define a quantity $\mathrm{pw} H$, the value of which is readily obtained from emf measurements of cell III [6]:

$$
\mathrm{pw} \mathrm{H} \equiv-\log \left(f_{\mathrm{H}} f_{\mathrm{Cl}} m_{\mathrm{H}}\right)=\frac{\left(E-E^{\circ}\right) \boldsymbol{F}}{2.3026 R T}+\log m_{\mathrm{Cl}}
$$

where $m$ is molality, $f$ an activity coefficient on the molal scale, and $E^{\circ}$ the standard potential of the hydrogen-silver-chloride cell [7]. Values of $E^{\circ}$ and $2.3026 R T / \boldsymbol{F}$ in absolute volts are tabulated in an earlier publication [8]. The formal relationship between $\mathrm{pwH}$ and $\mathrm{pH}_{s}$ is simple:

$$
\mathrm{pH}_{s} \equiv \log \left(1 / \boldsymbol{a}_{\mathrm{H}}\right)=\mathrm{pwH}+\log f_{\mathrm{Cl}} .
$$

The $\mathrm{pH}$ of a chloride-free buffer solution can be writen similarly

$$
\mathrm{pH}_{s}=\mathrm{pwH}^{\circ}+\log f_{\mathrm{Cl}}^{\circ},
$$

where $\mathrm{pwH}^{\circ}$ and $f_{\mathrm{Cl}}^{\circ}$ are the limits of $\mathrm{pwH}$ and $f_{\mathrm{Cr}}$ as the molality of potassium chloride is reduced to zero.

The indeterminate character of the potential at the liquid junction precludes the exact calculation of hydrogen-ion activity from the emf of a cell in which a liquid junction is present. When the cell without liquid junction is chosen, it is necessary to evaluate the activity coefficient of a single ionic species in order to compute the activity, and this coefficient, like the liquid-junction potential, is not. amenable to measurement. For standardization purposes, however, the latter method has a very real advantage, for the uncertainty diminishes with decreasing ionic strength. Thus the $\mathrm{pH}_{s}$ values obtained from the cell without liquid junction become increasingly accurate as the concentration of dissolved electrolyte decreases $[6,9]$. On the other hand, the only recognized means of assuring the reduction of the residual liquid-junction potential to a negligible value appears to be the employment, in the preparation of the buffer solutions, of an artificial solvent medium containing a neutral salt in high concentration. This device has been used successfully to determine the concentrations of hydrogen 
ions in buffer solutions [10,11, 12], but the estimation of $\boldsymbol{a}_{H}$ for a buffer solution in such a medium is very difficult.

Ionic activity coefficients are often computed by the Debye-Hückel equation[13] for the variation of $f_{i}$ with ionic strength, $\mu$, in the form that allows for the restriction of attraction between ions due to their finite size:

$$
\log f_{i}=-A z_{i}^{2} \sqrt{\mu} /\left(1+B a_{i} \sqrt{\mu}\right),
$$

where $A$ and $B$ depend on the temperature and dielectric constant of the solvent, $z_{i}$ is the valence of the ion $i$ and $a_{i}$ is an adjustable parameter with the dimension of distance and order of magnitude of the ionic diameter. Equation 4 is of ten valuable as an interpolation and extrapolation formula. When it is tested with the mean activity coefficients of uniunivalent strong electrolytes at ionic strengths below 0.1 , the mean ionic diameter is usually found to lie between 7 and $3.5 \mathrm{~A}$, the Bjerrum lower limit for complete dissociation [14]. For example, when $a_{i}$ is 6 and $z_{i}$ is 1 , the calculated logarithm of the mean activity coefficient of hydrochloric acid differs from the observed value by 0.001 at $0.02 \mathrm{~m}, 0.002$ at 0.05 $\mathrm{m}, 0.000$ at $0.1 \mathrm{~m}$, and 0.006 at $0.2 \mathrm{~m}$. The usefulness of the equation can be extended to concentrations as high as $3 m$ by adding a term $\beta \mu$, where $\beta$ is a second adjustable parameter [15]. But at the lower concentrations there is nothing to be gained in the estimation of $f_{C_{1}}$ by introducing an empirical term linear in ionic strength.

Although an equation of the form of eq 4 doubtless expresses the variation of $f_{\mathrm{C} \boldsymbol{}}$ with ionic strength at low concentrations, it is impossible to ascertain the proper value of $a_{i}$. Various reasonable methods of estimating this parameter lead to results differing by more than 0.01 unit in $\log f_{\mathrm{C} 1}^{\circ}$ and $\mathrm{pH}_{s}$ when the ionic strength exceeds 0.1 [6]. The safest procedure is to choose standard buffer solutions of as low concentration as is consistent with an adequate buffer capacity. Under these conditions any reasonable value of $a_{i}$ will yield $\mathrm{pH}_{s}$ values with uncertainties less than the arbitrary tolerances of about 0.01 to 0.02 unit.

From measurements of the emf of cells of type III, $\mathrm{pH}$ values from $0^{\circ}$ to $60^{\circ}$ have been assigned by the National Bureau of Standards to three buffer standards: acid potassium phthalate, $\mathrm{pH}$ about 4; a mixture of potassium dihydrogen phosphate and disodium hydrogen phosphate, $\mathrm{pH}$ about 7 ; and borax, $\mathrm{pH}$ about 9 . These solutions serve to calibrate $\mathrm{pH}$ equipment for use in the range $\mathrm{pH} 3$ to 11 . In this intermediate region of acidities, the potential at the junction between saturated potassium chloride and a variety of buffer solutions is believed to be fairly uniform. This conclusion is affirmed by the fact that other semithermodynamic $\mathrm{pH}$ scales based upon the emf of hydrogen-calomel cells with liquid junction $[16,17]$ furnish almost the same values for the three NBS standards as were assigned from measurements of hydrogen-silver-chloride cells without liquid junction. But with solutions that contain appreciable amounts of strong acids or bases, the highly mobile hydrogen and hydroxyl ions cause the liquid-junction potential to be altered.

The object of the present study was twofold. The first purpose was to examine a series of promising standards for the ranges of bigh acidity and high alkalinity with a view to selecting the most suitable materials to fix the practical $\mathrm{pH}$ scale at one or more points below $\mathrm{pH} 4$ and above $\mathrm{pH} 9$. The second purpose was to demonstrate the extent of the error in practical measurements at the ends of the $\mathrm{pH}$ scale that results from variation of the liquid-junction potential as one standard buffer solution is replaced by another or by an unknown. solution. To accomplish this object, differences of $\mathrm{pH}$ were calculated from measurements of the cell without liquid junction and compared with the result afforded by the usual cell with liquid junction.

Studies were made at $25^{\circ} \mathrm{C}$ of 41 promising standard solutions with $\mathrm{pH}$ from 1.1 to 13.3 . Twenty-one of these solutions were investigated at $0^{\circ}, 10^{\circ}, 25^{\circ}$, and $38^{\circ} \mathrm{C}$, and one at $25^{\circ}$ and $38^{\circ}$ alone, by emf measurements of hydrogen-silver-cbloride cells without liquid junction. The data for 24 solutions are used to elucidate the extent of aberration of the practical $\mathrm{pH}$ scale at its extremes. The results suggest that solutions of the following materials are suitable standards for $\mathrm{pH}$ : Potassium tetroxalate dihydrate, potassium hydrogen tartrate, a mixture of sodium acid succinate and sodium succinate, a mixture of sodium bicarbonate and sodium carbonate, and trisodium phosphate.

\section{Apparatus and Procedure}

The determination of $\mathrm{pH}$ on the practical scale is based upon two or more measurements of a cell such as type I. One measurement must be a calibration with a standard buffer solution. The practical scale overlooks possible changes in the liquid-junction potential, but any failure of the glass electrode to respond to hydrogen-ion activity in the manner of the standard hydrogen electrode must be allowed for by application of appropriate corrections. Hence, cell II is the basis for the determination of $\mathrm{pH}$ values. The direct measurement of the emf of this cell is probably the most accurate means of studying the practical scale and of determining the $\mathrm{pH}$ of secondary standards.

The cell vessel illustrated in figure 1 was designed expressly for the determination of the emf, $E-E_{s}$, of cells of type II. It consists essentially of a reservoir, a, of saturated potassium chloride solution; a double mercury-calomel electrode, $b$, of the saturated type; and two hydrogen-electrode compartments, $c$ and $c^{\prime}$. The liquid junctions are formed in the bulbs e and $e^{\prime}$, and each is protected from the disturbing effect of the bubbling hydrogen by a glass bead that forms an imperfect closure at the top. This arrangement has been used by Hitchock and Taylor [16]. The calomel electrode is unnecessary when the reference is a hydrogen electrode in a standard buffer solution. Therefore, the calome 


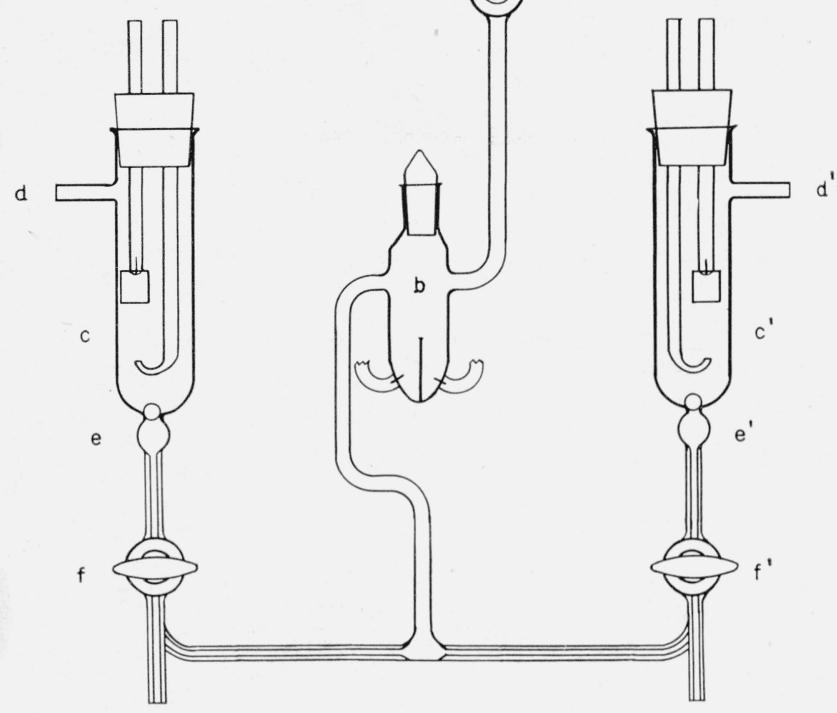

FIGURE 1. Cell vessel for emf measurements of cells of type II. a, Reservoir of saturated $\mathrm{KCl}$; b, calomel electrode; c, $\mathrm{c}^{\prime}$, hydrogen electrodes.

electrode was omitted in the construction of one of the two cells used in this study. It was found useful in the first cell, however, to determine the time required for the hydrogen electrodes to reach equilibrium and to observe the stability of the reference buffer. The 0.025- $M$ phosphate solution with $\mathrm{pH}$ near neutrality was used as the standard in all measurements of cell II.

The saturated solution of potassium chloride was formed by dissolving the bromide-free fused salt [18] in water at $60^{\circ}$ to $70^{\circ} \mathrm{C}$ and cooling to room temperature. A few drops of a solution of the sodium salt of methyl red were added to aid in making the junctions visible. The calomel electrodes were prepared by grinding calomel, pure mercury, and crystals of pure potassium chloride with a small amount of the saturated solution of potassium chloride and transferring the thick paste to compartment b, each leg of which contained a little mercury.

Fresh hydrogen electrodes were prepared daily by electrolysis of the platinum foils for about 2 min at $300 \mathrm{ma}$ in a 3-percent solution of chloroplatinic acid containing $80 \mathrm{mg}$ of lead acetate trihydrate in each $100 \mathrm{ml}$. The foils were coated with palladium for use in the phthalate solutions [19]. The purified hydrogen was not usually saturated with water vapor before entering the cell. However, the gas that was led into the carbonate solutions had been passed through a presaturator containing some of the same solution. Hydrogen escaped from the cell through $d$ and $d$ '. To equalize the pressure in the two electrode compartments, these led to a T-tube and a common exit.

The cell was rinsed twice with each solution and drained through the three-way stopcocks $\mathrm{f}$ and $\mathrm{f}^{\prime}$ before it was filled and the solutions adjusted to approximately the same level in each arm. The cell was then placed in the constant-temperature bath and the flow of hydrogen started. After $1 / 2$ to $1 \mathrm{hr}$ it was removed in order that the liquid junctions could be formed. The following procedure was adopted to avoid disturbance of the junctions resulting from slight differences of solution level. The stopcock at a was opened and potassium chloride solution brought about halfway up the capillary tubes above $f$ and $f^{\prime}$. With both $f$ and $f^{\prime}$ open, the junctions were brought simultaneously to the center of the bulbs e and $\mathrm{e}^{\prime}$ by admitting potassium chloride solution through a. Stopcocks $f$ and $f^{\prime}$ were closed while the cell was being returned to the bath but were opened immediately thereafter and measurements begun. The hydrogen electrodes usually reached equilibrium in 10 to $20 \mathrm{~min}$ thereafter. The emf, $E-E_{s}$, which represents the difference of potential between the hydrogen electrodes, was often constant as soon as the junctions were made and remained so within \pm 0.1 to $0.2 \mathrm{mv}$ for 30 to 90 $\min$.

The cells without liquid junction (type III) have been described previously [20]. For the measurements of carbonate solutions, the hydrogen was passed, before entering the cell, through a presaturator of three chambers each containing cell solution [8]. The electrode supports and the interior of the cells and solution flasks were coated with paraffin for most of the measurements of solutions of sodium hydroxide and trisodium phosphate, with some improvement in the constancy of the emf. The silver-silver-chloride electrodes were prepared by forming approximately $150 \mathrm{mg}$ of silver on platinum helices by thermal decomposition of a paste of wellwashed silver oxide at $550^{\circ}$. These silver electrodes were then chloridized by electrolysis for $45 \mathrm{~min}$ at a current of $7 \mathrm{ma}$ in a $1-M$ solution of distilled hydrochloric acid. Each cell contained two hydrogen electrodes and two silver-silver-chloride electrodes. The recorded emf is thus the mean of two observed values.

In order to obtain data which would furnish an accurate value of $\mathrm{pwH}^{\circ}$, the limit of $\mathrm{pwH}(\mathrm{eq} 2)$ as the chloride concentration approaches zero, emf measurements were made on three portions of each buffer solution, to which different amounts of potassium chloride had been added. The molalities of chloride selected for this purpose were 0.015 , 0.01 , and 0.005 . The temperature measurements were made with a platinum resistance thermometer and bridge or with a calibrated mercury thermometer. 


\section{Material}

The 41 solutions chosen for a study of the practical $\mathrm{pH}$ scale and for examination as to their suitability for use as standards are listed approximately in order of increasing $\mathrm{pH}$ in the tables of the following sections. The same order will be observed here.

The hydrochloric acid solution was prepared from a distilled sample and was analyzed gravimetrically. The emf found with a $0.0993-M$ solution was corrected by $0.18 \mathrm{mv}$ to obtain the emf of the $0.1-M$ solution. The mixture of hydrochloric acid and potassium chloride was prepared by dilution of the $0.0993-M$ solution of acid and addition of bromidefree potassium chloride.

A commercial sample of anhydrous sulfamic acid, $\mathrm{NH}_{2}-\mathrm{SO}_{3} \mathrm{H}$ was used without further purification. The composition was unchanged by drying at $105^{\circ}$, as shown by titration with standard alkali.

Some difficulty was experienced in obtaining potassium tetroxalate dihydrate of the theoretical composition by recrystallization from water and drying in air. However, a procedure was ultimately found that yielded a pure product. Reagent-grade salt was crystallized twice from water, the two components being taken in such amounts that no crystals separated above $50^{\circ}$. The mixture was cooled to $10^{\circ}$, and the crystals were collected on a sinteredglass funnel. The product was finely ground and dried overnight at $58^{\circ}$.

The anhydrous citric acid was furnished by Chas. Pfizer \& Co., Inc.

Two samples of potassium hydrogen tartrate were employed. The first was reagent-grade material. The second was obtained by recrystallization of the first and appeared to be of identical composition.

Potassium dihydrogen citrate was prepared as described elsewhere [21]. The total acidity of the product was found to be somewhat too low. The necessary amount of citric acid was therefore added, and the salt precipitated from aqueous solution by the addition of ethanol and by cooling. The salt was dried below $80^{\circ}$ and its titration value determined.

The potassium acid phthalate was NBS Standard Sample 185.

The acetic acid was purified by three fractional freezings. The acetic acid-sodium acetate buffer solutions were prepared by adding the required amount of a standardized solution of carbonate-free sodium hydroxide to a solution of the acid.

Preparation of the sodium hydrogen succinate and sodium succinate has been described [22].

NBS Standard Sample 187 of borax was used.

Lithium carbonate, which has a negative temperature coefficient of solubility, was prepared by adding a hot solution of lithium chloride to a vigorously stirred hot solution of potassium carbonate. It was washed by decantation with hot water until the washings gave no further test for chloride. The salt was heated to $450^{\circ}$ before use.

Potassium and sodium bicarbonate of reagent grade were found sufficiently pure without further treatment, as was sodium carbonate after heating at $270^{\circ}$ to $300^{\circ}$

Preliminary studies of calcium and barium hydroxides indicated that the saturated solutions of these substances would not be suitable as alkaline standards of readily reproducible $\mathrm{pH}$. Hence, the composition of the reagent-grade materials was not determined.

Attempts to prepare a pure carbonate-free sample of trisodium phosphate were unsuccessful. The commercial material contained about 2.5 mole percent of free alkali and about 8 moles of water per mole of salt. Although precipitation with ethanol removed the excess alkali with partial success, it appeared that a stable product with a definite water content between 0 and 12 moles per mole of salt would be difficult or impossible to obtain. The attempts were therefore abandoned in favor of forming the substance in solution from disodium hydrogen phosphate, NBS Standard Sample 186 II b, and a carbonate-free solution of sodium hydroxide.

The sodium hydroxide solution was made by dilution of a 50-percent solution from which the precipitated carbonate had been removed by centrifuging. Its concentration was determined by titration of samples of potassium acid phthalate, NBS Standard Sample 84c. The diluted solution gave a negative test for carbonate by the method suggested by Kolthoff and Sandell [23].

The reference $0.025-M$ phosphate buffer solution was prepared by dissolving $3.401 \mathrm{~g}$ (air weight) of potassium dihydrogen phosphate, Standard Sample $186 \mathrm{I} \mathrm{b}$, and $3.548 \mathrm{~g}$ (air weight) of disodium hydrogen phosphate, Standard Sample 186 II b, in sufficient water to make a liter of solution.

Freshly boiled water, protected from atmospheric carbon dioxide while cooling, was used for all the solutions. The $\mathrm{pH}$ of the water was 6.8 to 7.2 .

The results of the analyses of materials are summarized in table 1 . The titrations with acid and alkali were performed by weight methods. Endpoints were determined with suitable indicators. Phenol red was used in the titration of sulfamic acid to $\mathrm{pH}$ 7.5. Citric acid and potassium dihydrogen citrate were titrated to $\mathrm{pH} 9.0$ with the aid of thymol blue. The endpoint in the titration of tetroxalate and tartrate was taken to be $\mathrm{pH}$ 8.4, with phenolphthalein as the indicator. Phenolphthalein was also

TABLE 1. Results of analyses

\begin{tabular}{|c|c|c|}
\hline Material & Purity & Method \\
\hline $\begin{array}{l}\text { Sulfamic acid } \\
\text { Potassium tetroxalate. } 2 \mathrm{H}_{2} \mathrm{O} \\
\text { Citric acid } \\
\text { Potassium hydrogen tartrate } \\
\text { Potassium dihydrogen citrate } \\
\text { Sodium hydrogen succinate } \\
\text { Sodium succinate } \\
\text { Sodium bicarbonate } \\
\text { Potassium bicarbonate } \\
\text { Lithium carbonate } \\
\text { Sodium carbonate }\end{array}$ & $\begin{array}{c}\text { Percent } \\
99.77 \\
100.00 \\
100.03 \\
100.05 \\
100.01 \\
100.03 \\
99.99 \\
100.01 \\
99.99 \\
99.95 \\
100.00\end{array}$ & $\begin{array}{l}\text { Alkali titration. } \\
\text { Do. } \\
\text { Do. } \\
\text { Do. } \\
\text { Do. } \\
\text { Do. } \\
\text { Ignition to } \mathrm{Na}_{2} \mathrm{CO}_{3} \text {. } \\
\text { Acid titration. } \\
\text { Do. } \\
\text { Do. } \\
\text { Do. }\end{array}$ \\
\hline
\end{tabular}


used to titrate the acid succinate salt to $\mathrm{pH}$ 8.7. Bromcresol green was used in determining the purity of the bicarbonates and carbonates [23].

\section{Results}

\section{Cells with liquid junction, type II}

Table 2 is a summary of $\mathrm{E}-\mathrm{E}_{s}$ at $25^{\circ}$ and the $\mathrm{pH}$ values computed therefrom by eq 1 . Each entry is the mean of the measurements of at least two cells. The $\mathrm{pH}$ given by Hitcheock and Taylor $(\mathrm{H})[16]$ and MacInnes, Belcher, and Shedlovsky (M) [17] is noted in the last column. Kiehl and Loucks [24] have determined the $\mathrm{pH}$ of four of the alkaline solutions at $30^{\circ}$ by measurement of the emf of a hydrogen-calomel cell. Their values have been corrected to $25^{\circ}$ with the aid of temperature coefficients of $\mathrm{pH}$ derived from measurements of cell III. The results, given in the last column of table 2, are identified by $\mathbf{K}$.

TABLE 2. Electromotive force of cell II and $\mathrm{pH}$ from cells with liquid junction at $25^{\circ}$

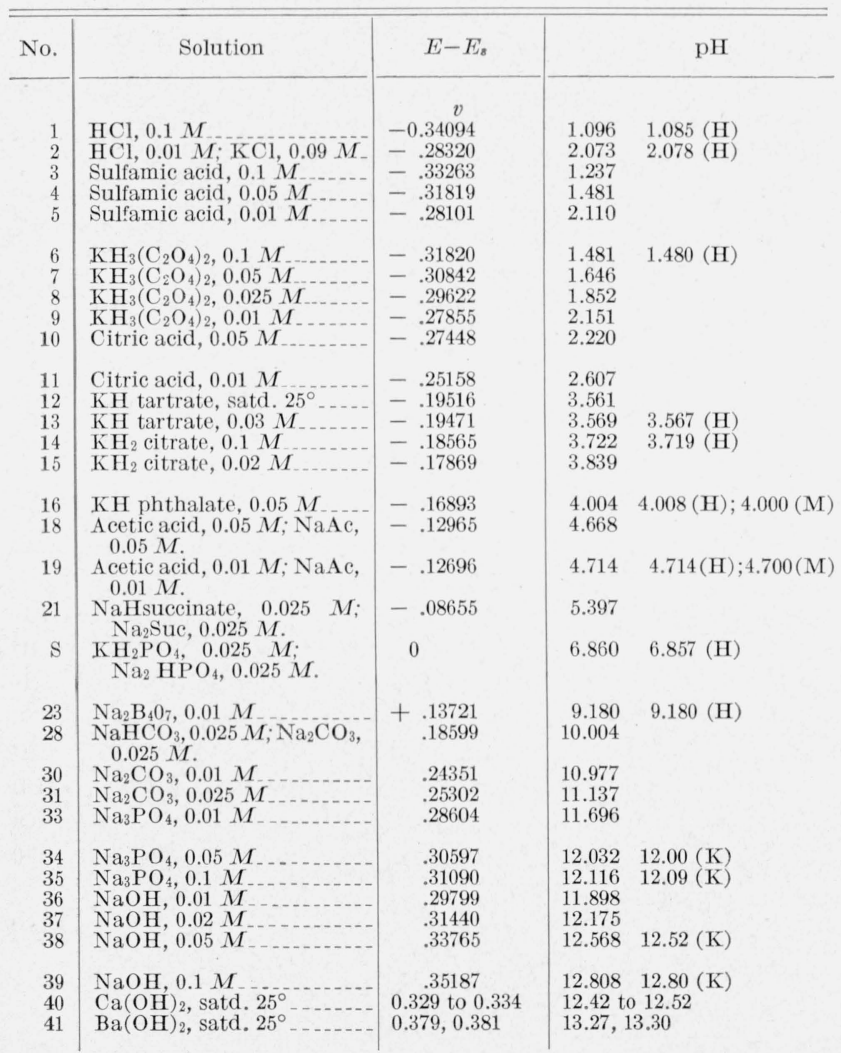

The $\mathrm{pH}$ of the reference $0.025-M$ phosphate buffer $\left(\mathrm{pH}_{s}\right)$ was taken to be 6.860 at $25^{\circ}$, the value derived from emf measurements of cells without liquid junction [25]. This agrees closely with 6.857 obtained from the emf of the hydrogen-calomel cell [16].

Six different phosphate solutions, designated by the letters $\mathrm{A}$ to $\mathrm{F}$, were prepared during the course of the study, and each was used for a period of 2 to 5 weeks. The reference solution was kept in a glassstoppered Pyrex bottle. Hitchcock and Taylor found the emf of phosphate and borax solutions repro- ducible to $0.1 \mathrm{mv}$ only when the solutions were freshly prepared [16]. Although the variation of $E_{s}$, the emf of the hydrogen-calomel cell containing phosphate solution, was slightly greater than 0.1 $\mathrm{mv}$ in this investigation, no trend in one or the other direction with age of the solution was observed. The values of $E-E_{s}$ appeared more reproducible than $\mathrm{E}_{s}$ alone. This observation suggests that the variations were caused, in part at least, by hysteresis of the calomel electrode, which was not kept at constant temperature between measurements. The potential of the calomel electrode is of no concern in discussions of cell II. As a matter of interest, however, the average $\mathrm{E}_{s}$ for each buffer solution and the corresponding potentials, $E^{\circ \prime}+E_{j}$ [6], of the calomel electrode are listed in table 3 . The liquidjunction potential between phosphate and saturated potassium chloride is included in $E^{\circ \prime}+\mathrm{E}_{j}$. These data are in absolute volts and are to be compared with 0.2442 from the study of Hitcheock and Taylor [16] and 0.2447 found by MacInnes, Belcher, and Shedlovsky [17]. TABLE 3. E for six 0.025-M phosphate solutions and $E^{\circ \prime}+E_{j}$,
the potential of the saturated calomel electrode at $25^{\circ}$

\begin{tabular}{|c|c|c|c|}
\hline $\begin{array}{l}\text { Phosphate } \\
\text { solution }\end{array}$ & $\begin{array}{l}\text { Number } \\
\text { of Meas- } \\
\text { urements }\end{array}$ & $E_{s}$ & $E^{\circ \prime}+E_{j}$ \\
\hline $\begin{array}{l}\mathrm{A} \ldots \ldots \\
\mathrm{B} \ldots \ldots \\
\mathrm{C} \\
\mathrm{D} \\
\mathrm{E} \\
\mathrm{F}\end{array}$ & $\begin{array}{l}16 \\
12 \\
15 \\
12 \\
16 \\
15\end{array}$ & $\begin{array}{r}v^{v} \\
0.65052 \pm 0.00012 \\
.65051 \pm 0.00025 \\
.65064 \pm 0.00013 \\
.65047 \pm 0.00006 \\
.65043 \pm 0.00004 \\
.65018 \pm 0.00011\end{array}$ & $\begin{array}{c}v \\
0.2447 \\
.2447 \\
.2448 \\
.2447 \\
.2446 \\
.2444\end{array}$ \\
\hline
\end{tabular}

\section{Cells Without Liquid Junction, Type III}

The emf at $0^{\circ}, 10^{\circ}, 25^{\circ}$, and $38^{\circ}$ of cells of type III is given in tables 4 and 5 . Each figure is the mean potential between two separate pairs of electrodes in the same cell, corrected to a partial pressure of $1 \mathrm{~atm}$ of hydrogen. The pwH value calculated by eq 2 from each value of $E$ at $0^{\circ}, 25^{\circ}$, and $38^{\circ}$ is plotted in figures 2 to 5 as a function of the molality of potassium chloride. The data for the acid solutions are shown in figure 2, for the carbonate buffers in figure 3 , for the solutions of sodium carbonate in figure 4 , and for sodium hydroxide and trisodium phosphate in figure 5 . The solutions are identified by number and by circles and dots, the significance of which is noted in the accompanying legends. The intercepts at zero chloride, $\mathrm{pwH}^{\circ}$, were read from large-scale plots similar to figures 2 , 3,4 , and 5 . Tables 6 and 7 summarize $\mathrm{pwH}^{\circ}$ and include similar data from the literature, where available, for solutions included in this study. The source of $\mathrm{pwH}^{\circ}$ or the emf data from which it was computed is indicated in the last column of table 6 . The pwH of $0.05-M$ sodium hydroxide solution was obtained by adding 0.017 , the value of $\log (0.05 /$ $0.04809)$, to $\mathrm{pwH}$ for the $0.04809-M$ solution actually studied. This correction is based on the assumption that the ratio of the activity coefficients of chloride and hydroxide ions is substantially the same at these two concentrations. 
5.5
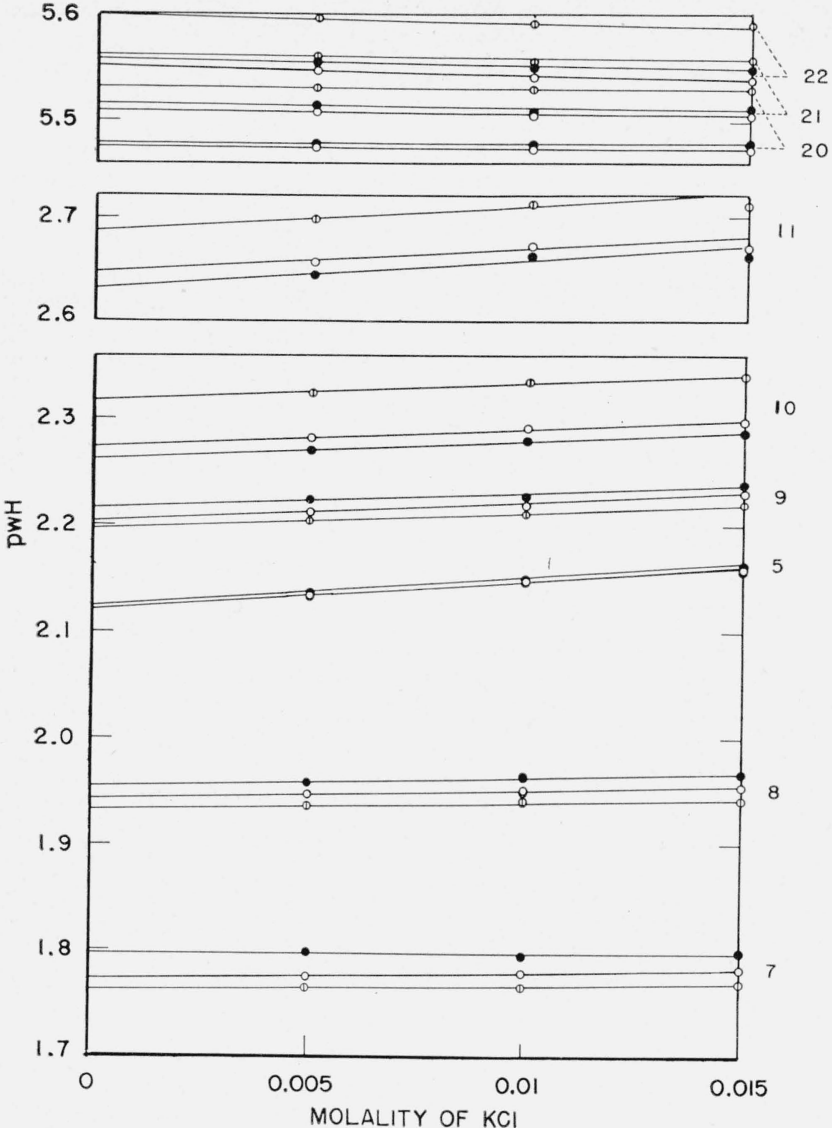

FIGURE 2. pwH of acid solutions as a function of the molality of added potassium chloride.

Marked circles, $0^{\circ}$; open circles, $25^{\circ}$; dots, $38^{\circ}$. Solution numbers appear at the right.

TABLE 4. Electromotive force of cell III at $0^{\circ}, 10^{\circ}, 25^{\circ}$, and $38^{\circ}$ (Acid solutions)

\begin{tabular}{|c|c|c|c|c|c|c|}
\hline \multirow{2}{*}{ No. } & \multirow{2}{*}{ Solution } & \multirow{2}{*}{$\mathrm{KCl}$} & \multicolumn{4}{|c|}{ Electromotive force at- } \\
\hline & & & $0^{\circ}$ & $10^{\circ}$ & $25^{\circ}$ & $38^{\circ}$ \\
\hline \multirow{4}{*}{5} & \multirow{4}{*}{ Sulfamic acid, $0.01 M$} & 0 & 10 & 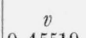 & & $v$ \\
\hline & & $\left\{\begin{array}{l}0.015 \\
.01\end{array}\right.$ & $\begin{array}{r}0.45259 \\
.46160\end{array}$ & $\begin{array}{r}0.45519 \\
.46442\end{array}$ & $\begin{array}{r}0.45810 \\
.46789\end{array}$ & $\begin{array}{r}0,45972 \\
.46969\end{array}$ \\
\hline & & .005 & .47703 & .48060 & .48480 & .48746 \\
\hline & & .015 & .43125 & .43340 & .43581 & .43721 \\
\hline \multirow[t]{3}{*}{7} & \multirow[t]{3}{*}{$\mathrm{KH}_{3}\left(\mathrm{C}_{2} \mathrm{O}_{4}\right)_{2}, 0.05 \mathrm{M}$} & .01 & .44064 & .44320 & .44603 & .44792 \\
\hline & & .005 & .45687 & .46009 & .46361 & .46667 \\
\hline & & .015 & .44062 & .44309 & .44597 & .44762 \\
\hline \multirow[t]{3}{*}{8} & \multirow{3}{*}{$\mathrm{KH}_{3}\left(\mathrm{C}_{2} \mathrm{O}_{4}\right)_{2}, 0.025 \mathrm{M}$} & .01 & .44999 & .45291 & .45622 & .45834 \\
\hline & & .005 & .45007 & .45268 & .45615 & .45831 \\
\hline & & .015 & .45579 & 45889 & $\begin{array}{l}.47374 \\
.46228\end{array}$ & $\begin{array}{r}.4 / 005 \\
.46441\end{array}$ \\
\hline \multirow[t]{2}{*}{9} & \multirow{2}{*}{$\mathrm{KH}\left(\mathrm{C}_{2} \mathrm{O}_{4}\right)_{2}, 0.01 \mathrm{M} \ldots$} & .01 & .46476 & .46812 & .47206 & $\begin{array}{r}47464 \\
40292\end{array}$ \\
\hline & & .005 & .48072 & .48472 & .48944 & .49292 \\
\hline \multirow{3}{*}{10} & \multirow{3}{*}{ Citric acid, $0.05 M_{-}$} & .015 & .46222 & .46419 & .46631 & $\begin{array}{r}46743 \\
47781\end{array}$ \\
\hline & & .005 & $\begin{array}{l}.4751 \\
.48721\end{array}$ & $\begin{array}{l}.47374 \\
.49007\end{array}$ & $\begin{array}{r}.47635 \\
.49354\end{array}$ & .47781 \\
\hline & & .015 & .48226 & .48501 & .48832 & .49064 \\
\hline \multirow[t]{2}{*}{11} & \multirow[t]{2}{*}{ Citric acid, $0.01 M_{-}$} & .01 & .49196 & .49501 & . 49889 & . 50149 \\
\hline & & $\begin{array}{r}.005 \\
015\end{array}$ & .50741 & .51104 & .51577 & $\begin{array}{r}.51896 \\
66436\end{array}$ \\
\hline \multirow{2}{*}{20} & \multirow{2}{*}{$\begin{array}{l}\text { NaHsuccinate, } \quad 0.05 M \\
\text { Na }\end{array}$} & $\begin{array}{l}.015 \\
.01\end{array}$ & $\begin{array}{l}.63504 \\
.64465\end{array}$ & $\begin{array}{l}.64263 \\
.65252\end{array}$ & $\begin{array}{r}65415 \\
.66458\end{array}$ & $\begin{array}{r}66436 \\
.67522\end{array}$ \\
\hline & & .005 & .66099 & .66951 & .68241 & .69382 \\
\hline \multirow[t]{2}{*}{21} & \multirow{2}{*}{$\begin{array}{c}\mathrm{NaHSuc}, 0.025 M \text {; } \mathrm{Na}_{2} \mathrm{Suc}, \\
0.025 M\end{array}$} & .015 & .63659 & .64431 & $\begin{array}{r}65599 \\
66638\end{array}$ & $\begin{array}{r}66644 \\
67712\end{array}$ \\
\hline & & .01 & $\begin{array}{l}.64606 \\
.66256\end{array}$ & $\begin{array}{l}.65411 \\
.67123\end{array}$ & $\begin{array}{r}.66638 \\
.68440\end{array}$ & $\begin{array}{l}.67712 \\
.69611\end{array}$ \\
\hline \multirow[t]{2}{*}{22} & \multirow{2}{*}{$\begin{array}{l}\text { NaHSuc, } 0.01 M \text {; Na }{ }_{2} \text { Suc, } \\
0.01 \mathrm{M}\end{array}$} & .015 & . 63835 & .64619 & .65802 & .66875 \\
\hline & & $\begin{array}{l}.01 \\
.005\end{array}$ & $\begin{array}{l}.64794 \\
.66455\end{array}$ & $\begin{array}{l}.65614 \\
.67336\end{array}$ & $\begin{array}{l}.66858 \\
.68671\end{array}$ & $\begin{array}{l}.67974 \\
.69861\end{array}$ \\
\hline
\end{tabular}
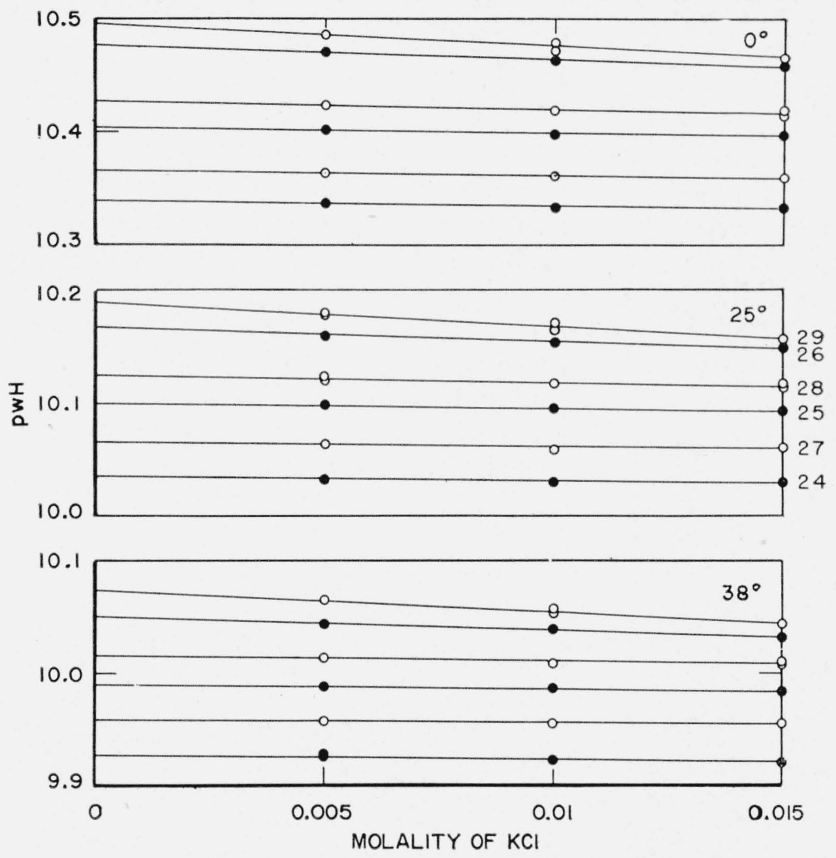

FIGURE 3. pwH of bicarbonate-carbonate buffers as a function of the molality of added potassium chloride.

Dots, $\mathrm{KHCO}_{3}-\mathrm{Li}_{2} \mathrm{CO}_{3}$ mixtures; circles, $\mathrm{NaHCO}_{3}-\mathrm{Na}_{2} \mathrm{CO}_{3}$ mixtures. Solution numbers appear at the right.
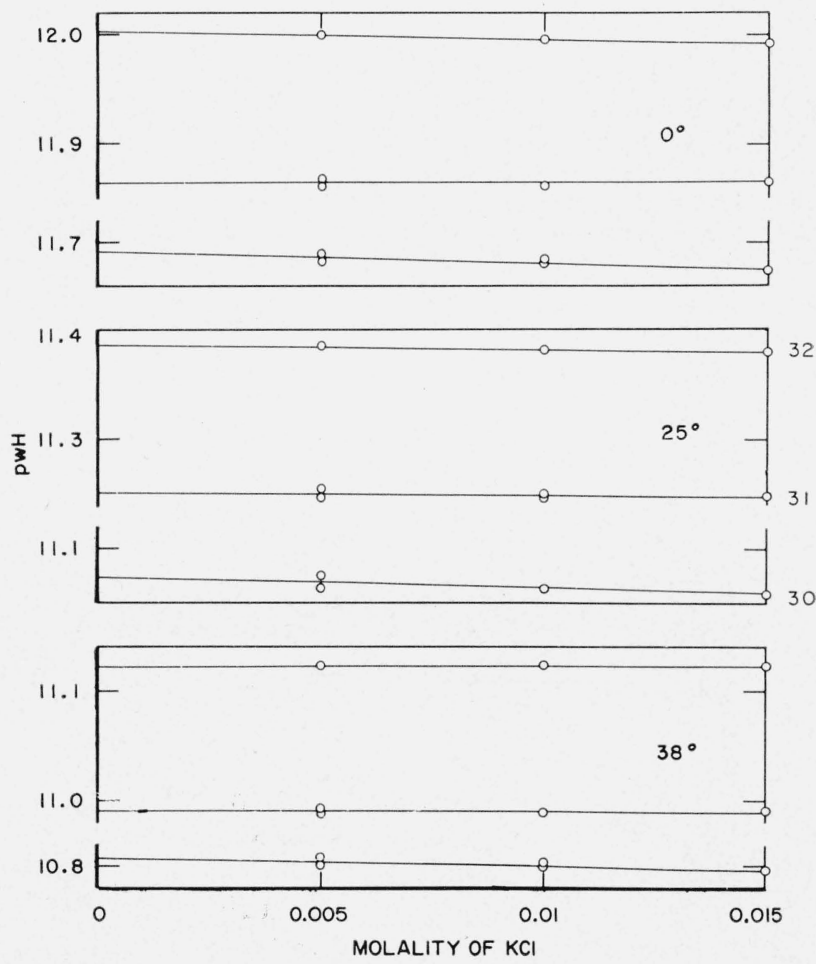

FIGURE 4. pwH of sodium carbonate solutions as a function of the molality of added potassium chloride.

Solution numbers appear at the right. 


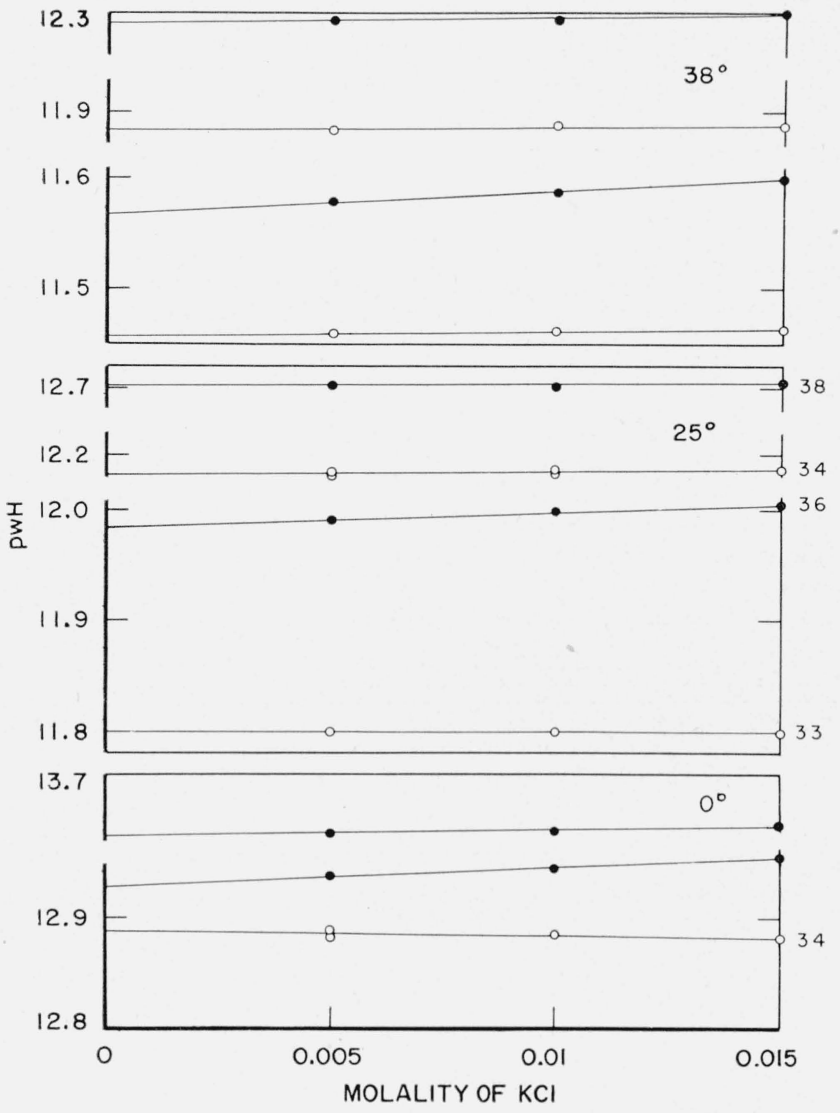

FIGURE 5. pwH of trisodium phosphate and sodium hydroxide solutions as a function of the molality of added potassium chloride.

Circles, $\mathrm{Na}_{3} \mathrm{PO}_{4}$ solutions; dots, $\mathrm{NaOH}$ solutions. Solution numbers appear at the right.

TABLE 5. Electromotive force of cell III at $0^{\circ}, 10^{\circ}, 25^{\circ}$, and $38^{\circ}$

[Alkaline solutions]

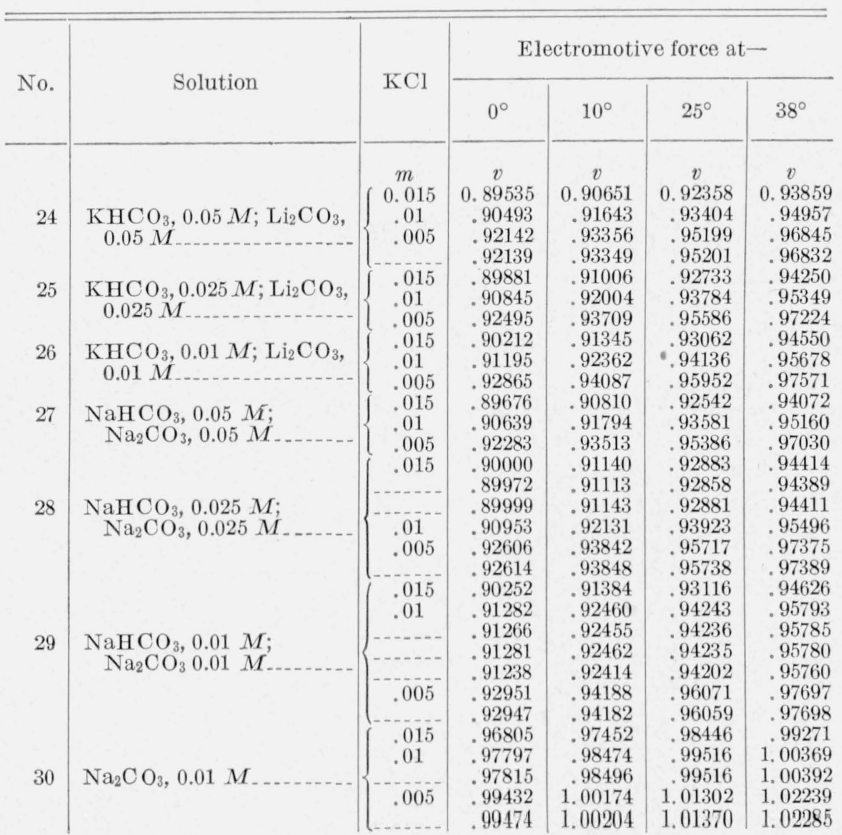

TABLE 5. Electromotive force of cell III at $0^{\circ}, 10^{\circ}, 25^{\circ}$, and $38^{\circ}$-Continued

[Alkaline solutions]

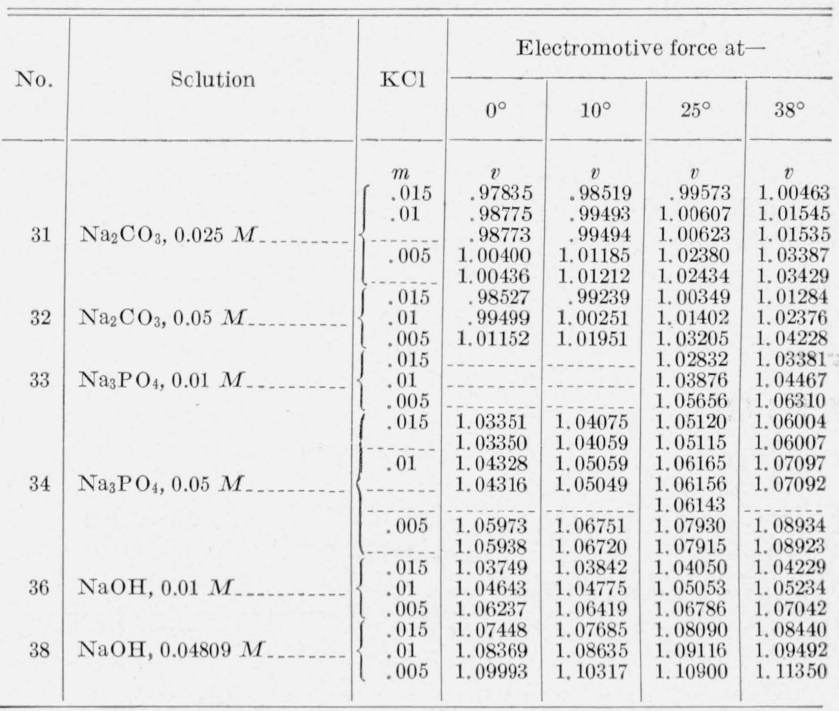

TABLE 6. $\mathrm{pw} \mathrm{H}^{\circ}$ at $0^{\circ}, 10^{\circ}, 25^{\circ}$, and $38^{\circ}$

[Acid solutions]

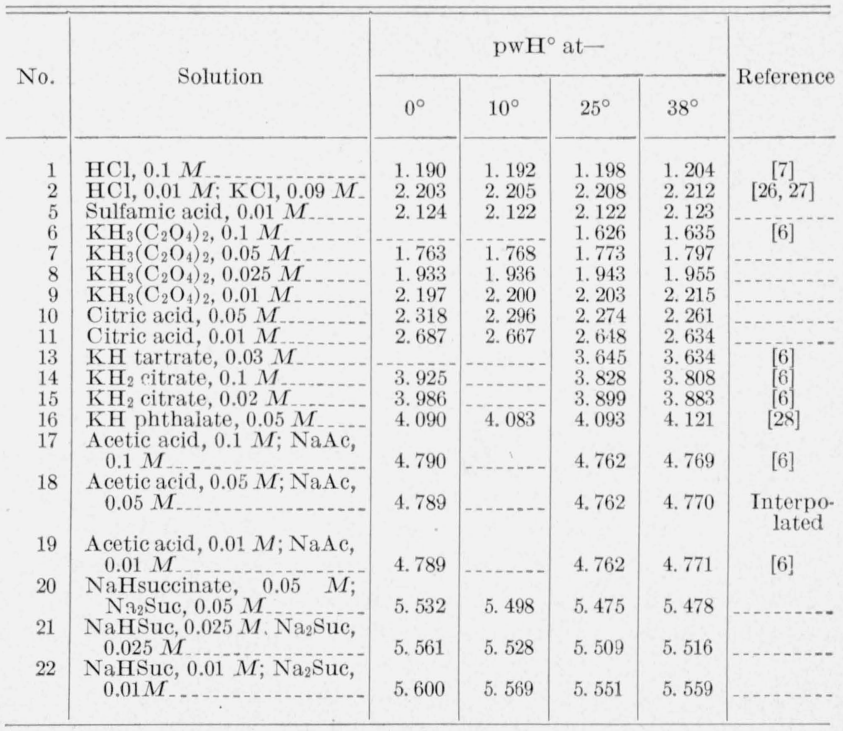

TABLE 7. $\mathrm{pwH}^{\circ}$ at $0^{\circ}, 10^{\circ}, 25^{\circ}$, and $38^{\circ}$

[Alkaline solutions]

\begin{tabular}{|c|c|c|c|c|c|}
\hline \multirow{2}{*}{ No. } & \multirow{2}{*}{ Solution } & \multicolumn{4}{|c|}{ pw $\mathrm{H}^{\circ}$ at- } \\
\hline & & $0^{\circ}$ & $10^{\circ}$ & $25^{\circ}$ & $38^{\circ}$ \\
\hline 23 & $\mathrm{Na}_{2} \mathrm{~B}_{4} \mathrm{O}_{7}, 0.01 M \mathrm{a}$ & 9.522 & 9.388 & 9.240 & 9. 145 \\
\hline 24 & $\mathrm{KHCO}_{3}, 0.05 \mathrm{M} ; \mathrm{Li}_{2} \mathrm{CO}_{3}, 0.05 \mathrm{M}$ & 10.339 & 10.199 & 10. 034 & 9.927 \\
\hline 25 & $\mathrm{KHCO}_{3}, 0.025 \mathrm{M} ; \mathrm{Li}_{2} \mathrm{CO}_{3}, 0.025 \mathrm{M}$ & 10.404 & 10.263 & 10. 099 & 9.990 \\
\hline 26 & $\mathrm{KHCO}_{3}, 0.01 M ; \mathrm{Li}_{2} \mathrm{CO}_{3}, 0.01 M$ & 10.476 & 10.333 & 10.165 & 10.050 \\
\hline 27 & $\mathrm{NaHCO}_{3}, 0.05 M ; \mathrm{Na}_{2} \mathrm{CO}_{3}, 0.05 M$ & 10.365 & 10. 227 & 10.065 & 9.958 \\
\hline 28 & $\mathrm{NaHCO}_{3}, 0.025 M ; \mathrm{Na}_{2} \mathrm{CO}_{3}, 0.025 M$. & 10.427 & 10.288 & 10. 124 & 10.015 \\
\hline 29 & $\mathrm{NaHCO}_{3}, 0.01 M ; \mathrm{Na}_{2} \mathrm{CO}_{3}, 0.01 M$ & 10.495 & 10.355 & 10. 189 & 10.074 \\
\hline 30 & $\mathrm{Na}_{2} \mathrm{CO}_{3}, 0.01 M$ & 11.692 & 11. 422 & 11.074 & 10.807 \\
\hline 31 & $\mathrm{Na}_{2} \mathrm{CO}_{3}, 0.025 \mathrm{M}$ & 11.864 & 11. 594 & 11. 251 & 10.990 \\
\hline 32 & $\mathrm{Na}_{2} \mathrm{CO}_{3}, 0.05 \mathrm{M}$ & 12.003 & 11.730 & 11.386 & 11.122 \\
\hline 33 & $\mathrm{Na}_{3} \mathrm{PO}_{4}, 0.01 M$ & & & 11.800 & 11.458 \\
\hline 34 & $\mathrm{Na}_{3} \mathrm{PO}_{4}, 0.05 \mathrm{M}$ & 12.888 & 12.580 & 12.182 & 11. 884 \\
\hline 36 & $\mathrm{NaOH}, 0.01 M_{-}$ & 12.928 & 12.514 & 11.983 & 11. 567 \\
\hline 38 & $\mathrm{NaOH}, 0.05 \mathrm{M}$ & 13.645 & 13.229 & 12. 702 & 12.290 \\
\hline
\end{tabular}

a Values for borax ealculated from data of [29]. 


\section{Calculations and Discussion}

The Brønsted theory of specific ionic interaction [30] is founded upon the hypothesis that the activity coefficients of ions are influenced differently by the specific characteristics of the ions of opposite sign composing the medium and in a like manner by other ions of like charge which, through repulsion, are presumed beyond the reach of short range forces. Although the studies of Güntelberg [31], Scatchard and Prentiss [32], Harned [27], and others indicate that Brønsted's treatment is somewhat oversimplified, they serve to confirm this primary postulate. Hence, the activity coefficient of chloride ion needed to compute a $\mathrm{pH}$ value from $\mathrm{pwH}$ is probably influenced not only by the ionic strength but to some extent by the kinds of cations present.

When hydrochloric acid is replaced either partially or completely by alkali chloride at constant ionic strength, the activity coefficient of the acid decreases [27]. This means that the ion-size parameter of eq 4 also decreases. Inasmuch as no change has taken place in the anionic composition of the medium, it is not unreasonable to assume that the replacement of hydrogen ion by alkali metal ion results in a decrease of $a_{i}$ for the acid. The activity coefficient of chloride ion in a pure dilute solution of hydrochloric acid is believed to approximate the mean activity coefficient of the acid. Furthermore, the ion-size parameter for the latter ranges from 6 , for pure hydrochloric acid, to 5.0 to 5.4 , for hydrochloric acid in pure sodium chloride and pure potassium chloride. ${ }^{2}$ Hence, if $a_{i}$ for chloride ion in mixtures containing sodium and potassium ions is assumed to be approximately the same as the ion-size parameter for hydrochloric acid in the mixtures, a choice of 4 to 6 can be justified. The uncertainty in $f_{\mathrm{Cl}}^{\circ}$ and in the $\mathrm{pH}_{s}$ computed by eq 3a must be at least as great as the difference between the results furnished by these two reasonable values of $a_{i}$.

The $\mathrm{pH}_{s}$ values given in tables 8 and 9 were computed from $\mathrm{pwH}^{\circ}$ by eq 3a. At each of the four temperatures, $f_{\mathrm{Cl}}^{\circ}$ was estimated by eq 4 with $a_{i}$ equal to 5 . The approximate ionic strengths, $\mu$, were obtained with the aid of the concentrations of hydrogen and hydroxyl ions derived from the $\mathrm{pH}$ given in table 2. For the acid salts, the ratio of constants for the overlapping equilibria was used, together with $m_{\mathrm{H}}$. The formula for the calculation appears in an earlier contribution [34]. In order to indicate the uncertainty of the values given in the tables, the difference, $\delta \mathrm{pH}$, between the $\mathrm{pH}_{s}$ furnished by $a_{i}=4$ and $a_{i}=6$ at $25^{\circ}$ is listed in the last column of each table.

\footnotetext{
${ }^{2}$ Cesium chloride lowers the parameter still more [33].
}

TABLE 8. $\mathrm{pH}_{s}$ from cells without liquid junction (type III)

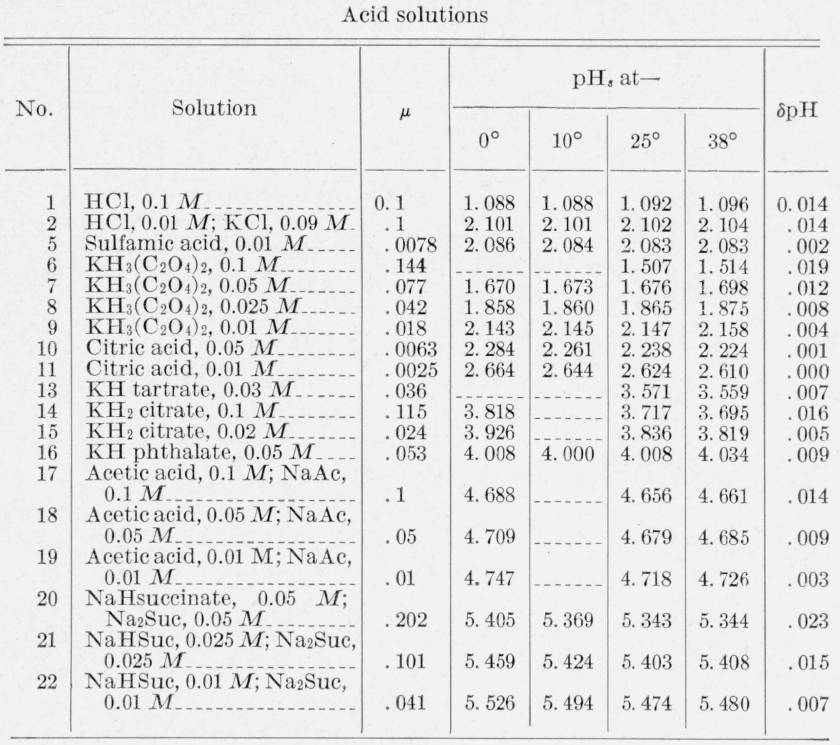

TABLE 9.- $-\mathrm{pH}_{s}$ from cells without liquid junction (type III)

\begin{tabular}{|c|c|c|c|c|c|c|c|}
\hline \multirow{2}{*}{ No. } & \multirow{2}{*}{ Solutions } & \multirow{2}{*}{$\mu$} & \multicolumn{4}{|c|}{$\mathrm{pH}_{s}$ at- } & \multirow{2}{*}{$\delta \mathrm{pH}$} \\
\hline & & & $0^{\circ}$ & $10^{\circ}$ & $25^{\circ}$ & $38^{\circ}$ & \\
\hline \multirow{2}{*}{$\begin{array}{l}23 \\
24\end{array}$} & $\mathrm{Na}_{2} \mathrm{~B}_{4} \mathrm{O}_{7}, 0.01 M$ & 0.02 & 9. 466 & 9. 331 & 9.181 & 9.085 & 0.005 \\
\hline & $\mathrm{K} \mathrm{HOO}_{3}, 0.05 \quad M$ & & & & & & 022 \\
\hline \multirow[t]{2}{*}{25} & $\mathrm{KHCO}, 0.025 \mathrm{M}$; & .2 & 10.212 & $10.0 \%$ & 9.902 & 9.793 & .022 \\
\hline & 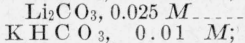 & .1 & 10. 302 & 10.159 & 9.993 & 9.882 & .014 \\
\hline 26 & $\mathrm{Li}_{2} \mathrm{CO}_{3}, 0.01 \mathrm{M}$ & .04 & 10.402 & 10.258 & 9.088 & 9. 972 & .008 \\
\hline 27 & $\mathrm{Na}_{2} \mathrm{CO}_{3}, 0.05 M_{-}$ & .2 & 10.238 & 10.098 & 9.933 & 9.824 & .022 \\
\hline 28 & $\begin{array}{c}\mathrm{NaH} \mathrm{CO}_{3}, 0.025 M ; \\
\mathrm{Na}_{2} \mathrm{CO}_{3}, 0.025 M\end{array}$ & & 10.32 & 20.000 & 10.018 & 9.907 & 014 \\
\hline \multirow[t]{2}{*}{29} & $\mathrm{NaHCO}_{3}, \quad 0.01, M$ & & & & & 9.906 & .014 \\
\hline & $\mathrm{Na}_{2} \mathrm{CO}_{3}, 0.01 M_{-}$ & .04 & 10.421 & 10. 280 & 10.112 & 9. 996 & .008 \\
\hline 30 & $\mathrm{Na}_{2} \mathrm{CO}_{3}, 0.01 M$ & .029 & 11. 627 & 11.356 & 11.006 & 10.738 & .006 \\
\hline 31 & $\mathrm{Na}_{2} \mathrm{CO}_{3}, 0.025 \mathrm{M}$ & .074 & 11. 772 & 11.500 & 11.155 & 10.892 & .012 \\
\hline 32 & $\mathrm{Na}_{2} \mathrm{CO}_{3}, 0.05 \mathrm{M}$ & .148 & 11.887 & 11.612 & 11.266 & 11.000 & .019 \\
\hline 33 & $\mathrm{Na}_{3} \mathrm{PO}_{4}, 0.01 M$ & .047 & & & 11.719 & 11.375 & .009 \\
\hline 34 & $\mathrm{Na}_{3} \mathrm{PO}_{4}, 0.05 M_{-}$ & .27 & 12. 750 & 12. 440 & 12. 039 & 11.739 & .026 \\
\hline 36 & $\mathrm{NaOH}, 0.01 M_{-}$ & .01 & 12.886 & 12. 471 & 11.939 & 11.522 & .003 \\
\hline 38 & $\mathrm{NaOH}, 0.05 \mathrm{M}_{--}$ & .05 & 13.565 & 13.148 & 12.616 & 12.205 & .009 \\
\hline
\end{tabular}

\section{Nature of the practical $\mathrm{pH}$ scale}

The practical $\mathrm{pH}$ scale is defined in terms of the emf of cells of type II. In the $\mathrm{pH}$ meter, the emf of cell II is obtained as the difference between two measurements, one of which is the standardization with a solution of known $\mathrm{pH}$. Saturated potassium chloride is interposed between the unknown and the standard buffer solution in an attempt to lower the liquid-junction potentials to a small constant value. Although these potentials at the boundaries between 


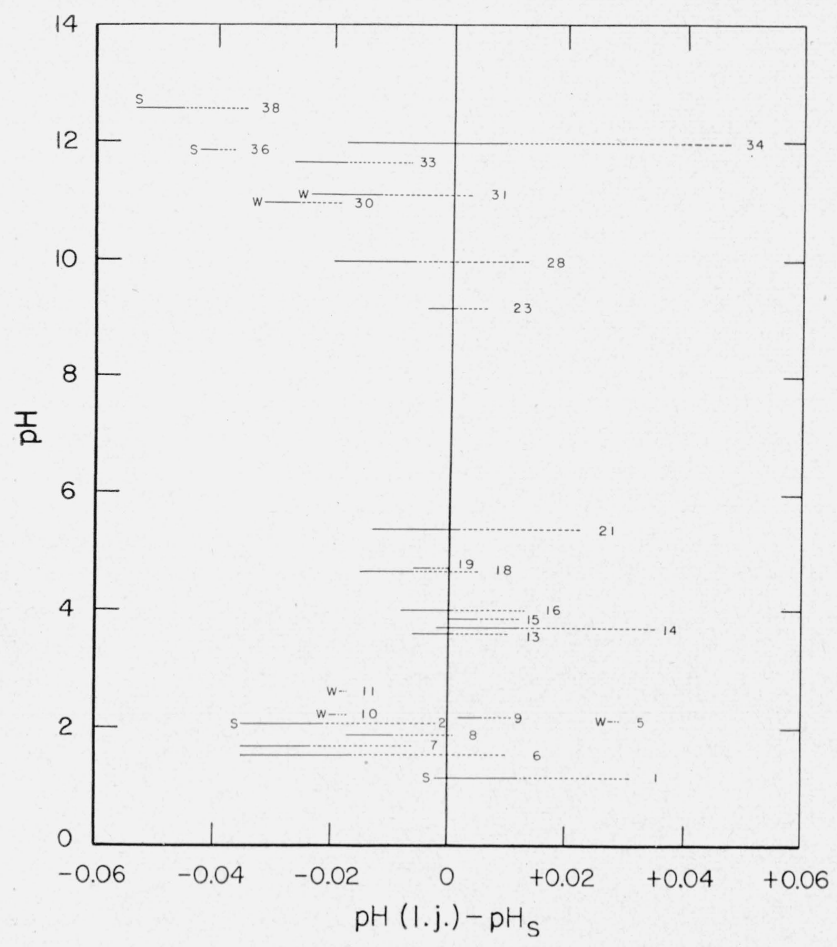

FiguRE 6. Liquid-junction error of the practical $\mathrm{pH}$ scale. Solid line corresponds to the most probable range, 4 to 6 , for the ion-size parameter. Broken line represents values from 2 to 4 . Solution numbers appear beside the lines. $\mathrm{S}$ and $\mathrm{W}$ identify solutions of strong and weak electrolytes, respectively; the remainder are buffer solutions.

the saturated solution of potassium chloride and the unknown and standard solutions cannot be eliminated, it is hopefully assumed that their difference is small or zero, and no correction for residual liquidjunction potentials is made.

Figure 6 compares the $\mathrm{pH}$ furnished by the practical measurement of cells of type II (phosphate standard) with the value (designated $\mathrm{pH}_{s}$ ) computed from the cell without liquid junction. The uncertainty in $a_{i}$ is indicated by the length of the lines. The solid lines represent $\mathrm{pH}$ (l. j.) $-\mathrm{pH}_{s}$ for $a_{i}$ between 4 and 6 and the broken lines between 2 and 4. It is considered likely that the proper value lies between 4 and 6 . The solution number appears beside each line. $\mathrm{S}$ identifies solutions containing strong acid or base, and W identifies solutions of weak acids and sodium carbonate. The remainder are buffer solutions.

Hydrogen and hydroxyl have the highest mobilities of any of the ions. Hence, one would expect, from simple qualitative considerations, to find that $\mathrm{pH}$ (l. j.) $-\mathrm{pH}_{s}$ is positive for strongly acid solutions and negative for strongly alkaline ones. However, as figure 6 shows, negative values were found for some acid solutions as well as for those of high $\mathrm{pH}$. Such a result might be attributed to a transfer of anions, present in concentrations greatly exceeding that of the hydrogen ion, across the boundary.

The potential differences at the boundary between solutions such as those studied here cannot be measured or calculated with accuracy. Even when ideal behavior for each ionic species is assumed and activity set equal to molality, a particular distribution of the ions through the boundary must be assumed, and the transference number of each must be known in all of the transition layers formed by diffusion or mixing of the two end solutions. Nevertheless, a further examination of the liquid-junction errors apparent in figure 6 seemed worth while.

There are two liquid junctions in a cell of type II. Each can be represented by

\section{Solution $\mid$ satd. $\mathrm{KCl} ; E_{j}$,}

where $E_{j}$ is the potential difference across the boundary represented by the vertical line. The resulting error in $\mathrm{pH}, \Delta \mathrm{pH}$, at $25^{\circ}$ is

$$
\Delta \mathrm{pH}=E_{j} / 0.059154-E_{j(s)} / 0.059154,
$$

where $E_{j(s)}$ indicates the potential at the boundary between the standard phosphate solution and saturated potassium chloride.

If the boundary is of the "continuous mixture" type, the equation developed by Henderson [35] applies. These junctions actually correspond more closely to the "free diffusion" type. Although the diffusion junction is easily set up and reproducible, it is difficult to treat theoretically. The Henderson equation can be written

$$
E_{j} / 0.059154=\frac{\left(U_{1}-V_{1}\right)-\left(U_{2}-V_{2}\right)}{\left(U_{1}^{\prime}+V_{1}^{\prime}\right)-\left(U_{2}^{\prime}+V_{2}^{\prime}\right)} \log \frac{\left(U_{1}^{\prime}+V_{1}^{\prime}\right)}{\left(U_{2}^{\prime}+V_{2}^{\prime}\right)} .
$$

If the ionic mobilities in each solution are taken equal to the mobilities at infinite dilution, $\lambda^{\circ} / \boldsymbol{F}$, where $\lambda^{\circ}$ is the limiting equivalent ionic conductance and $\boldsymbol{F}$ is the faraday, we have the following formulas:

$$
\begin{aligned}
U & \equiv \Sigma c_{+} \lambda_{+}^{\circ}, \\
V & \equiv \Sigma c_{-} \lambda_{-}^{\circ}, \\
U^{\prime} & \equiv \Sigma c_{+} \lambda_{+}^{\circ}\left|z_{+}\right|, \\
V^{\prime} & \equiv \Sigma c_{-} \lambda_{-}^{\circ}\left|z_{-}\right| .
\end{aligned}
$$

The subscript 1 refers to the standard phosphate buffer or other solution in question, and 2 refers in each case to the saturated solution of potassium chloride; $c$ is the ionic concentration ( $g$ ions per liter) and $\left|z_{+}\right|$and $\left|z_{-}\right|$are the absolute values of the valences of the ions.

The error, $\Delta \mathrm{pH}$, computed from eq 5 and 6 is compared in table 10 with the corresponding "observed" difference, $\mathrm{pH}$ (l. j.) $-\mathrm{pH}_{\text {s. }}$.The ion-size parameter, $a_{i}$, was taken to be 4 for the calculation of $\mathrm{pH}_{s}$ from $\mathrm{pwH}^{\circ}$. The limiting equivalent conductances of the ions were taken from the literature and from the list given in Harned and Owen's monograph [33]. The conductances of carbonate ion, secondary and tertiary phosphate ions, primary cit- 
rate ion, and secondary phthalate ion were estimated from those of other ions of like charge and similar structure. Hydrolysis and dissociation were considered in computing the required ionic concentrations.

TABLE 10. Liquid-junction error of the practical $\mathrm{pH}$ scale with the phosphate buffer as primary standard

Comparison of "observed" $\mathrm{pH}$ (l. j.) $-\mathrm{pH}_{8}$ with $\Delta \mathrm{pH}$ calculated by the Hender-

\begin{tabular}{|c|c|c|c|}
\hline No. & Solution & $\begin{array}{c}\text { Observed } \\
\text { pŁ }\left(1 . \mathrm{j}^{\prime}\right)- \\
\mathrm{pH}_{s}\end{array}$ & $\begin{array}{l}\text { Calcu- } \\
\text { lated } \\
\Delta \mathrm{pH}\end{array}$ \\
\hline 1 & $\mathrm{HCl}, 0.1 \mathrm{M}$ & +0.012 & +0.038 \\
\hline 2 & $\mathrm{HCl}, 0.01 M ; \mathrm{KCl}, 0.09 M_{-}$ & -.021 & -.004 \\
\hline 6 & $\mathrm{KH}_{3}\left(\mathrm{C}_{2} \mathrm{O}_{4}\right)_{2}, 0.1 \mathrm{M}$ & -.016 & +.024 \\
\hline 7 & $\mathrm{KH}_{3}\left(\mathrm{C}_{2} \mathrm{O}_{4}\right)_{2}, 0.05 \mathrm{M}$ & -.023 & +.013 \\
\hline 8 & $\mathrm{KH}_{3}\left(\mathrm{C}_{2} \mathrm{O}_{4}\right)_{2}, 0.025 \mathrm{M}$ & -.009 & +.012 \\
\hline 9 & $\mathrm{KH}_{3}\left(\mathrm{C}_{2} \mathrm{O}_{4}\right)_{2}, 0.01 M_{-}$ & +.006 & +.010 \\
\hline 10 & Citric acid, $0.05 M$ & -.019 & +.012 \\
\hline 11 & Citric acid, $0.01 M$ & -.018 & +.016 \\
\hline 14 & $\mathrm{KH}_{2}$ citrate, $0.1 \mathrm{M}$ & +.012 & +.005 \\
\hline 15 & $\mathrm{KH}_{2}$ citrate, $0.02 \mathrm{M}_{-}$ & +.005 & +.009 \\
\hline 16 & $\mathrm{KH}$ phthalate, $0.05 \mathrm{M}$ & +.001 & +.001 \\
\hline 18 & Acetic acid, $0.05 M$; NaAc, $0.05 M$ & -.006 & .000 \\
\hline 19 & A cetic acid, $0.01 M$; NaAc, $0.01 M$ & -.003 & +.013 \\
\hline 28 & $\mathrm{NaHCO}_{3}, 0.025 M ; \mathrm{Na}_{2} \mathrm{CO}_{3}, 0.025 M_{\ldots \ldots}$ & -.006 & -.003 \\
\hline 30 & $\mathrm{Na}_{2} \mathrm{CO}_{3}, 0.01 M$ & -.026 & +.004 \\
\hline 31 & $\mathrm{Na}_{2} \mathrm{CO}_{3}, 0.025 \mathrm{M}$ & -.012 & -.001 \\
\hline 33 & $\mathrm{Na}_{3} \mathrm{PO}_{4}, 0.01 M_{-}$ & -.018 & -.003 \\
\hline 34 & $\mathrm{Na}_{3} \mathrm{PO}_{4}, 0.05 M_{-}$ & +.009 & -.013 \\
\hline 36 & $\mathrm{NaOH}, 0.01 M$ & -.040 & -.018 \\
\hline 38 & $\mathrm{NaOH}, 0.05 M_{-}$ & -.046 & -.029 \\
\hline
\end{tabular}

In general, $\mathrm{pH}(\mathrm{l}$. j. $)-\mathrm{pH}_{s}$ is less than the calculated error by 0.01 to 0.04 unit. A smaller $a_{i}$ would compensate in some measure for the discrepancy. Nevertheless, the approximations made in the calculation, together with the assumptions involved in the use of the Henderson equation, are probably chiefly responsible. It is perhaps significant that the difference is large for solutions of potassium tetroxalate and solutions of citric acid, both of which contain appreciable amounts of molecular acid. The agreement is good for the most dilute $(0.01-M)$ solution of potassium tetroxalate and for potassium dihydrogen citrate, potassium acid phthalate, the acetate buffers, and the 1:1 carbonate buffer. All of these are well-buffered solutions, and none has a $\mathrm{pH}$ value below 2 or above 10.1. The calculation appears to confirm the belief that the potential at the liquid junction between $0.01-M$ hydrochloric acid, $0.09-M$ potassium chloride and the saturated potassium chloride solution matches the corresponding potential for common buffer solutions much more closely than does that for $0.1-M$ hydrochloric acid. The observed $\mathrm{pH}$ difference, however, does not agree as well as might be desired.

Figure 6 demonstrates the consistency of the three NBS pH standards, namely the reference phosphate, the phthalate buffer (No. 16) and the borax buffer (No. 23). It also shows that low $\mathrm{pH}$ values are usually obtained from cells with liquid junction in strongly alkaline solutions, for the values of $\mathrm{pH}($ l.j. $)-\mathrm{pH}_{s}$ are too large in general to attribute to the uncertainty in $\mathrm{pH}_{s}$. This error may amount to 0.05 unit or more and is in the same direction as the alkaline error of the glass electrode. The error in acid solutions may be as great as 0.03 unit and be either in the direction of too high or too low $\mathrm{pH}$.

\section{2. $\mathrm{pH}$ standards of high acidity and high alkalinity}

There are two reasons why standards of low and high $\mathrm{pH}$ are needed. First, if $\mathrm{pH}$ at the ends of the practical scale is to be interpreted in terms of the activity of hydrogen ion, a means of rectifying the aberration apparent in figure 6 should be sought. Standards of which the assigned $\mathrm{pH}$ has significance in terms of hydrogen ion and whose liquid-junction errors match those of the majority of unknowns of comparable $\mathrm{pH}$ would provide a partial solution to the problem. It appears, for example, that measurements on the practical scale are approximately correct at $\mathrm{pH} 10$, about 0.02 unit low at $\mathrm{pH} 11$ to 12 , and about 0.04 unit low at $\mathrm{pH} 13$. Thus a standard of $\mathrm{pH} 11$ to 12 might reduce the error of measurements in the range $\mathrm{pH} 10$ to 13 to \pm 0.02 unit. However, this procedure offers little help at $\mathrm{pH}$ values below 2.5, where the errors may be either positive or negative. Present standards are adequate between $\mathrm{pH} 2.5$ and 10.5 .

In the second place, new $\mathrm{pH}$ standards of high acidity and alkalinity would improve the accuracy of measurement in these regions by reducing the $\mathrm{pH}$ span between unknown and standard. In this way the errors caused by differences in temperature between the two solutions or failure to adjust the instrument to the proper emf $/ \mathrm{pH}$ slope would be minimized. Glass-electrode errors would also be compensated to some extent.

A choice of suitable standards entails consideration of the purity and stability of the materials from which the standard solution is prepared, the stability of the solution itself, and the magnitude of the residual liquid-junction potential compared, as in figure 6 , with other typical solutions in the same $\mathrm{pH}$ range. In general, buffer solutions form the sharpest, most reproducible junctions. The following paragraphs summarize the properties, desirable and undesirable, of the materials included in the present study.

Sulfamic acid did not appear to be appreciably hygroscopic, but its solution displayed an abnormal liquid-junction potential. Potassium tetroxalate dihydrate can be obtained as a pure solid, stable in air at ordinary temperatures and humidities. The $\mathrm{pH}$ of the $0.05-M$ solution increased only 0.01 unit in 90 days. The liquid-junction error of the 0.01- $M$ solution is negligible.

Citric acid, potassium dihydrogen citrate, and potassium hydrogen tartrate can be obtained in pure form, but their solutions support mold growth. The saturated solution of potassium hydrogen tartrate (about $0.034 M$ ) is a useful standard that is easily prepared [36]. However, it must be renewed every few days, for mold appears in from 1 to 4 weeks and is accompanied by an increase in $\mathrm{pH}$ of 0.02 to 0.1 unit [37]. The standard $0.05-M$ phthalate buffer solution was found to be mold-free after 130 days. The $\mathrm{pH}$ had increased only 0.005 unit.

Acetate buffer solutions are good standards but are difficult to prepare. The succinate salts have little tendency to absorb moisture [22], and their solutions are satisfactorily stable, as are those of sodium and potassium bicarbonates. Succinate 
solutions may mold several weeks after preparation. Lithium and sodium carbonates have the distinct disadvantage of requiring ignition before use. Pure solid trisodium phosphate could not be prepared, but its solution was formed from equal molal amounts of solid disodium hydrogen phosphate and of sodium hydroxide (in aqueous solution). As a result of extensive hydrolysis, the buffer capacity of such solutions is high. The $\mathrm{pH}$ of a $0.025-M$ solution of trisodium phosphate was found to be altered less than 0.02 unit by addition of 4 mole percent of sodium hydroxide or an equal amount of disodium hydrogen phosphate. The $\mathrm{pH}$ of the $0.05-\mathrm{M}$ solution, preserved in a paraffin-lined bottle which was occasionally opened, decreased only 0.004 unit in 90 days and 0.008 unit in 140 days.

The solution of trisodium phosphate can be used for the calibration of high-alkalinity glass electrodes. When an uncertainty of \pm 0.05 unit is permissible, solutions of sodium hydroxide will also be found useful for this purpose. The $\mathrm{pH}$ at $25^{\circ}$ computed from the ionization constant of water and the activity coefficient of hydroxide ion, assuming the latter to be the same as the mean activity coefficient of the solute, is 12.61 for the $0.05-M$ solution and 12.88 for the $0.1-M$ solution. This value for $0.05-M$ sodium hydroxide is in close agreement with 12.616 computed from the emf of cell III. However, the two calculations are not completely independent, inasmuch as the value for the ionization constant of water rests in part on measurements of cells of type III. Between $25^{\circ}$ and $30^{\circ}$, the $\mathrm{pH}$ of these solutions of sodium hydroxide decreases about 0.03 unit for each degree increase in temperature.

Five buffer solutions are recommended:

\begin{tabular}{|c|c|c|c|c|}
\hline \multirow{2}{*}{ Solution } & \multicolumn{4}{|c|}{$\mathrm{pH}_{s}$ at- } \\
\hline & $0^{\circ}$ & $10^{\circ}$ & $25^{\circ}$ & $38^{\circ}$ \\
\hline $\begin{array}{l}\text { Potassium tetroxalate, } 0.01 \\
M\end{array}$ & \multirow[t]{2}{*}{ 2. 14} & \multirow[t]{2}{*}{ 2. 15} & \multirow[t]{2}{*}{ 2. 15} & 2. 16 \\
\hline $\begin{array}{l}\text { Potassium hydrogen tar- } \\
\text { trate (satd. at room } \\
\text { temperature) }\end{array}$ & & & & 3. 55 \\
\hline $\begin{array}{l}\text { Sodium acid succinate, } \\
0.025 M ; \text { sodium succi- } \\
\text { nate, } 0.025 M\end{array}$ & 5. 46 & 5. 42 & 5. 40 & 5. 41 \\
\hline $\begin{array}{l}\text { Sodium bicarbonate, } 0.025 \\
M ; \text { sodium carbonate, } \\
0.025 M^{2}\end{array}$ & \multirow[t]{2}{*}{ 10. 32} & \multirow[t]{2}{*}{ 10. 18} & \multirow{2}{*}{$\begin{array}{l}\text { 10. } 02 \\
\text { 11. } 72\end{array}$} & \multirow{2}{*}{$\begin{array}{r}9.91 \\
\text { 11. } 38\end{array}$} \\
\hline $\begin{array}{l}\text { Trisodium phosphate, } 0.01 \\
M\end{array}$ & & & & \\
\hline
\end{tabular}

These values are probably reliable to about \pm 0.01 unit. The $\mathrm{pH}$ of the acid standards is little affected by temperature changes. On the other hand, rather careful control of temperature is essential to accurate measurement of $\mathrm{pH}$ at high alkalinities.

\section{References}

[1] W. M. Clark, The determination of hydrogen ions, 3d ed. (The Williams \& Wilkins Co., Baltimore, Md., 1928).

[2] G. Kortüm, Z. Elektrochem. 48, 145 (1942).

[3] D. A. MacInnes, Science 108, 693 (1948).

[4] E. R. Smith and R. G. Bates, Compt. rend., p. 118 Quinzième Conférence, International Union of Pure and Applied Chemistry, Amsterdam (1949).

[5] J. W. M. Du Mond and E. R. Cohen, Rev. Modern Phys. 20, 82 (1948).

[6] R. G. Bates, Chem. Revs. 42, 1 (1948).

[7] H. S. Harned and R. W. Ehlers, J. Am. Chem. Soc. 55, 2179 (1933).

[8] R. G. Bates and G. D. Pinching, J. Research NBS 42, 419 (1949) RP1982.

[9] R. G. Bates and E. R. Smith, J. Wash. Acad. Sci. 38, 61 (1948).

[10] M. Kilpatrick and E. F. Chase, J. Am. Chem. Soc. 53, 1732 (1931).

[11] M. Kilpatrick, E. F. Chase, and L. C. Riesch, J. Am. Chem. Soc. 56, 2051 (1934).

[12] D. I. Hitchcock and R. Peters, J. Am. Chem. Soc. 68, 1753 (1946).

[13] P. Debye and E. Hückel, Physik. Z. 24, 185 (1923).

[14] N. Bjerrum, Kgl. Danske Videnskab. Selskab., Math.-fys. Medd. \%, No. 9 (1926).

[15] E. Hückel, Physik. Z. 26, 93 (1925).

[16] D. I. Hitcheock and A. C. Taylor, J. Am. Chem. Soc. 59, $1812(1937) ; \mathbf{6 0}, 2710(1938)$.

[17] D. A. MacInnes, D. Belcher, and T. Shedlovsky, J. Am. Chem. Soc. 60, 1094 (1938).

[18] G. D. Pinching and R. G. Bates, J. Research NBS 3\%, 311 (1946) RP1749.

[19] W. J. Hamer and S. F. Acree, J. Research NBS 33, 87 (1944) RP1598.

[20] R. G. Bates and S. F. Acree, J. Research NBS 30, 129 (1943) RP1524.

[21] R. G. Bates and G. D. Pinching, J. Am. Chem. Soc. 71, 1274 (1949).

[22] G. D. Pinching and R. G. Bates, J. Research NBS 45, (1950) RP2142.

[23] I. M. Kolthoff and E. B. Sandell, Textbook of quantitative inorganic analysis, p. 519, 524 (The Macmillan Co., New York, N. Y., 1937).

[24] S. J. Kiehl and R. D. Loucks, Trans. Electrochem. Soc. 6\%, 81 (1935).

[25] R. G. Bates and S. F. Acree, J. Research NBS 34, 373 (1945) RP1648.

[26] H. S. Harned and W. J. Hamer, J. Am. Chem. Soc. 55, 2194 (1933).

[27] H. S. Harned, J. Am. Chem. Soc. 57, 1865 (1935).

[28] W. J. Hamer and S. F. Acree, J. Research NBS 32, 215 (1944) RP1586.

[29] G. G. Manov, N. J. De Lollis, P. W. Lindvall, and S. F. Acree, J. Research NBS 36, 543 (1946) RP1721.

[30] J. N. Brønsted, J. Am. Chem. Soc. 44, 877 (1922); 45, 2898 (1923).

[31] E. Güntelberg, Z. physik. Chem. 123, 199 (1926).

[32] G. Scatchard and S. S. Prentiss, J. Am. Chem. Soc. 56, 2320 (1924).

[33] H. S. Harned and B. B. Owen, The physical chemistry of electrolytic solutions, chapter 14 and appendix (Reinhold Publishing Corp., New York, N. Y., 1943).

[34] R. G. Bates, J. Am. Chem. Soc. 70, 1579 (1948).

[35] P. Henderson, Z. physik. Chem. 59, 118 (1907); 63, 325 (1908).

[36] J. J. Lingane, Anal. Chem. 19, 810 (1947).

[37] R. G. Bates, Anal. chem. (publication pending).

Washington, July 6, 1950. 